\title{
Presenvation of Zobo Drink (Calyces of Hibiscus Sabdariffa) Using Kolanut
}

\author{
Bankole', Y.O. \\ Tanimola ${ }^{1}$, A.O. \\ Odunukan' ${ }^{1}$ R.O. \\ Samuel ${ }^{2}$, D.O. \\ ${ }^{1}$ Department of Agricultural \& Bio-Environmental Engineering, \\ Lagos State Polytechnic, Ikorodu-Nigeria \\ ${ }^{2}$ Department of Food Technology; School of Technology, \\ Lagos State Polytechnic, Ikorodu-Nigeria
}

\section{Doi:10.5901/ ajis.2013.v2n10p17}

\begin{abstract}
This study investigate the efficacy of two species of kolanut being Kola acuminate (ABATA) and Kola nitride (GBANJA) as antimicrobial agent in the preservation of Zobo drink from the calyces of Hybiscus sabdariffa which is commonly called ZOBO. $5 \mathrm{~m} / \mathrm{s}$ extracts of the caffeine was added to $50 \mathrm{~m} / \mathrm{s}$ of prepared Zobo drink using Escherichia coli (ATCC 23716) indicator organisms for 96hours. Physiochemical analysis for pH, Brix content, growth measurements of the indicator organisms were carried out at 24hourly interval starting at zero hour. The ash and caffeine contents were also noted for the Kolanut samples only. The results obtained from the various analyses were of immense benefit at enhancing the shelve stability of the drink and thereby making it available all the year round for its numerous consumers.
\end{abstract}

Keywords: Preservation, Zobo-Drink, Kolanut, Extract, Consumer.

\section{I ntroduction}

Additives are defined under the Food Labeling Regulations (1995) as any substances that are not commonly regarded or used as food which are added to, or used in or on food at any stage to affect its keeping qualities. Preservatives are chemical additives that are used to make foods have a desired shelf-life by preventing them from bacterial spoilage, retarding growth of molds and prevention from other chemicals that will change the food quality in terms of color, taste, aroma and texture.

In recent years, Nigeria obtains her food colors from the developing countries and regulations of these countries have been modified to a level that the conventional sources of food colors are limited. Reducing the supply of certain food colors with a polyphenol content of $67 \%$. Kolanut could serve as a potential source of food color. When the red nut is extracted with $50 \%$ methanol, it yields a reddish extract, which becomes deeper when extracted with $1 \%$ hydrochloric acid in methanol. The pod husk and also the testa contain high amount of pectin, which can be extracted and used in jam and jelly production.

Kolanut belongs to the family of Sterculiaceae. Its tree is an evergreen tree native to tropical Africa and it grows well in soils suitable for cocoa and coffee. The seeds are extensively used as a condiment by the natives of Western and Central tropical Africa, Kolanut constitute an important 
article to trade in West Africa because they are rich in caffeine.

There are different types of cola seeds derived from different species but there are just three edible ones in Nigeria. These include Kola acuminate popularly called Abata in Yoruba land and usually cherished for ceremonial uses. Kola nitida, which is known as the one used commercially because its consumption is very high and it is cherished amongst the Northerners. It is referred to as Gbanja amongst the Southerners. It consists of the separated cotyledons of the kernel of the seed; when fresh, it nearly white and on drying it undergoes a fermentation turning reddish brown and losing much of its astringency. Kola verticilata, this type is not eaten by many people especially Nigerians because of its sting taste but it can also be mentioned amongst the others.

Zobo, a non-alcoholic beverage popularly consumed in northern Nigeria is produced from the dried calyces of the rosell plant Hibiscus sabdariffa by boiling and filtration(Ameh et al, 2009). It is gaining wide acceptance, being consumed by severe millions of people from different socioeconomic classes and background. Zobo drink has been shown to be good source of natural carbohydrate, protein and vitamin $\mathrm{C}$ which constitutes the major reason for consuming soft drink and fruit juice (Braide, Oranusi and Peter-Ikechukwu, 2012). Several researchers have study the preparation and preservation of zobo drinks with different food items, such as lime. Nwachukwu, Onovo and Ezeama (2007) revealed that total coliforms and total viable counts generally decreased in values following treatment of zobo drink samples with lime juice.

Efforts have been made by researchers to find various uses of Kolanut but it has not been really satisfied in the area of food preservation. Kolanut contains caffeine serve as a stimulant and decreases fatigue. Although some studies have been employed in preservation of some fruit juices but its use as preservatives has not been fully exhausted. The use of chemical preservatives at small allowable concentrations to control the growth of microorganisms in beverages is desirable and gaining research interest worldwide (Nwafor and Ikenebomeh, 2009). It is on the basis of the preservative role of the caffeine from Kolanut that this study is conducted. Braide, et al (2012) stated that in spite of the increasing popularity of Zobo beverage, one of its limitations for large scale production is that it deteriorates rapidly. The drink contains microorganisms (Bacillus, Streptococcus, Staphylococcus, Leuconostoc, Lactobacillus, Aspergillus, Penicillium, Geotrichum, Fusarium and Alternaria). These lead to its spoilage. Therefore, the study will specifically addresses the following objectives:

1. To determine the physiochemical analysis on two popular species of Kolanut available in Nigeria.

2. To determine the preparation of caffeine extract from the two species of Kolanut.

3. To determine the preservative effect of the extract on zobo drink by studying the antimicrobial effects of the caffeine on selected strains of micro-organisms.

\section{Methods and Procedure}

Samples of the calyces of Hibiscus sabdariffa and sugar were obtained at Mile-12 market, Lagos state. Kolanut samples, Abata and Gbanja were also obtained from this same market. The samples were kept in clean transparent polythene bags and stored at room temperature of $28^{\circ} \mathrm{C}$. The calyces sample was prepared by sorting which involves the removal of unwanted particles such as dirt, stones, etc. The calyces of Hibiscus sabdariffa was extracted for its anthocyanin components using the hot water extraction method. $1000 \mathrm{mls}$ of hot water was added to $200 \mathrm{~g}$ of the calyces of Hybiscus sabdariffa, then boil for 5 minutes. This was left for 30 minutes to cool for removal of calyces using fine seive. Thereafter, $100 \mathrm{~g}$ of sugar was added to produce the Zobo drink.

The two species of Kolanut of interest Abata and Gbanja were extracted separately using the wet milling procedure. The Kolanut were washed and Cleaned, then weighed $80 \mathrm{~g}$. These $80 \mathrm{~g}$ was wet milled by adding $100 \mathrm{ml}$ distilled water and then strained with fine seive to remove unwanted solids. Centrifugation at 10,00r.p.m for 20 minutes was done to extract Kolanut and stored in refrigerator. Indicator organism for anti-microbial experimentation was Escherichia coli (ATCC 
23716) and was obtained from the culture collection unit, in the Department of Biotechnology, Federal Institute of Industrial Research, Oshodi. The organisms were maintained on Nutrient Agar slants at $4^{\circ} \mathrm{C}$ in the refrigerator.

\subsection{Experiments on the Antimicrobial Effects of Kolanut Extracts on Zobo Drink}

$50 \mathrm{mls}$ of Zobo drink was accurately measured into boiling tubes and $5 \mathrm{mls}$ of the Kolanut extracts was added to each tube and later autoclaved at $5 \mathrm{~kg}$ for 5 minutes using the autoclave. The tubes were allowed to cool to room temperature. On cooling, they were aseptically inoculated with colonies $(2.0 \times 10 \mathrm{cfu} / \mathrm{ml})$ of the test organisms. The inoculated tubes were allowed to remain at room temperature $\left(28 \pm 2^{\circ} \mathrm{C}\right)$ for 96 hours. At 24 hourly intervals, parameters which include brix reading, $\mathrm{pH}$ measurements, growth of the indicator organism were monitored and recorded.

\subsubsection{Determination of $\mathrm{pH}$ from samples}

The $\mathrm{pH}$ of the experimental samples were determined using the $\mathrm{pH}$ meter (unicam 9450 model) after its initial standardization to $\mathrm{pH} 4.0$ and 7.0

\subsubsection{Brix reading determination}

This was determined using the hand refractor-meter.

\subsection{Growth of indicator organisms: spectrophotometry mehtod}

The growth of indicator organisms for antimicrobial experimentation was carried out using the spectrophotomer (spectronic 20D model) at 540nm throughout the period of experimentation. The experimented sample was determined against the control sample that is, without the Kolanut extracts.

\subsubsection{Direct plate count method}

This was carried out by serial dilution of both the control sample and the experimental sample (Kolanut extracts) and placing out from 10 dilutions onto Nutrient agar plates using the pour plate method. The surface organisms were counted and recorded.

\subsection{Analysis of Kolanut Samples}

\subsubsection{Determination of the ash content}

$5 \mathrm{~g}$ of each Kolanut sample was separately weighed into porcelain crucible previously ignited and weighed organic matter was charred by igniting the material on a hot plate in a fume cupboard. The crucibles were placed in the muffle furnace and maintained at $600^{\circ} \mathrm{C}$ for 6 hours. They were then cooled in a desiccators and weighed immediately (AOAC, 1990).

$$
\% \text { Ash }=\frac{(\text { weightof crucible }+ \text { ash })-(\text { weight of empty crucible })}{\text { sample weight }} \times 100
$$




\subsection{Determination of the Caffeine Contents from Kolanut Samples}

\subsubsection{Gravimetric method}

This was carried out as described by Akoh, (1981) where $5.0 \mathrm{~g}$ of each Kolanut sample was separately weighed into $300 \mathrm{ml}$ flask. $10 \mathrm{~g}$ of magnesium oxide, $200 \mathrm{ml}$ was added and later boiled gently under reflux for 2 hours. This was later cooled and transferred to a $500 \mathrm{ml}$ volumetric flask, made up to mark with distilled water, mixed and later filtered. $300 \mathrm{mls}$ of the filtered sample was boiled with $15 \mathrm{ml}$ of $10 \%$ sulphuric acid until the volume drops to $100 \mathrm{ml}$. To this was added $10 \mathrm{ml}$ chloroform. The chloroform extract was later washed with $5 \mathrm{ml}$ of $1 \%$ potassium hydroxide solution. The chloroform was later evaporated to dryness in an oven at $100^{\circ} \mathrm{C}$ and weighed. The residue was later transferred to Kjedahl flask with small portions of concentrated sulphuric acid. This was later digested using Kjedahl catalyst ( 5 selenium tablets). This was later followed by distillation for 15 minutes (AOAC, 1990). The filtrate was then titrated against $0.05 \mathrm{~N} \mathrm{HCL}$. $\%$ Total Nitrogen $=$ Sample titer $(\mathrm{V} 2)-$ Blank titer $(\mathrm{VI}) \times 0.1 \times 0.014 \times 100$ Sample weight of Caffeine $=\% \mathrm{~N} 2 \times 3.464$.

\section{Results}

\subsection{Physiochemical Analysis of Kolanut Samples}

The Ash contents for the two (2) varieties of kola were calculated thus;

$$
\begin{aligned}
& \% \text { Ash }=\frac{\text { weght of crucible ash-weightof empty crucible) }}{\text { sample weight }} \times 100 \\
& \% \text { Ash for Abata }=\frac{(65.06-65.0)}{5} \times 10 \\
& =\quad \frac{0.06}{5} \times 100 \\
& =\quad 1.2 \% \\
& \% \text { Ash for Gbanja }=\frac{65.08-65.0}{5} \times 100 \\
& =\quad \frac{0.08}{5} \times 100 \\
& =\quad \underline{1.6 \%}
\end{aligned}
$$

\subsection{Caffeine Content Determination}

Caffeine $=\% \mathrm{~N} 2 \times 3.464$

$\%$ N2 = Sample titer (V2) - Blank titer (V1) $\times 0.1 \times 0.014 \times 100$

Sample weight for Abata:

$$
\begin{aligned}
& \% \mathrm{~N} 2=(18.5-12.40 \mathrm{mls}) \times 0.1 \times 0.014 \times 100 \\
& 1.00=0.854 \%
\end{aligned}
$$$$
\% \text { Caffeine }=0.854 \times 3.464=\underline{2.958 \%}
$$

Sample weight for Gbanja

$\% \mathrm{~N} 2=20.2-12.40 \times 0.1 \times 0.0 .014 \times 100$

1.00
$\%$ Caffeine $=1.092 \times 3.464={ }^{3.782 \%}$


Table 1: pH determination of samples

\begin{tabular}{|c|c|}
\hline Samples & pH Readings \\
\hline Gbanja & 5.66 \\
\hline Abata & 5.29 \\
\hline Zobo drink & 2.94 \\
\hline Zobo drink + Abata Extracts & 3.42 \\
\hline Zobo drink + Gbanja extracts & 3.50 \\
\hline
\end{tabular}

Table 2: Changes in the $\mathrm{pH}$ reading during antimicrobial experiment with zobo drink. $\mathrm{pH}$ reading/Time (Hour)

\begin{tabular}{|l|c|c|c|c|c|}
\hline \multicolumn{1}{|c|}{ Samples } & $\mathbf{0}$ & $\mathbf{2 4}$ & $\mathbf{4 8}$ & $\mathbf{7 2}$ & $\mathbf{9 6}$ \\
\hline Gbanja extracts with zobo drink & 3.50 & 3.20 & 2.70 & 2.50 & 2.50 \\
\hline Abata extracts with zobo drink & 3.42 & 3.30 & 3.24 & 3.20 & 3.18 \\
\hline Zobo drink without extracts & 2.94 & 3.38 & 4.50 & 6.20 & 6.54 \\
\hline
\end{tabular}

Table 3: Changes in the brix content during antimicrobial experiment with zobo drink

\begin{tabular}{|l|c|c|c|c|c|}
\hline & \multicolumn{5}{|c|}{ Brix Reading/Time (Hours } \\
\hline \multicolumn{1}{|c|}{ Samples } & $\mathbf{0}$ & $\mathbf{2 4}$ & $\mathbf{4 8}$ & $\mathbf{7 2}$ & $\mathbf{9 6}$ \\
\hline Gbanja extracts with zobo drink & 15.00 & 14.50 & 14.50 & 14.50 & 14.00 \\
\hline Abata extracts with zobo drink & 15.00 & 14.80 & 14.50 & 14.80 & 14.50 \\
\hline Zobo drink without Extract (control) & 15.00 & 8.00 & 6.00 & 4.00 & 2.00 \\
\hline
\end{tabular}

Table 4: Changes in the growth of Escherichia coli in zobo drink

\begin{tabular}{|l|c|c|c|c|c|}
\hline \multicolumn{7}{|c|}{ Growth (540nm)/Time (Hours) } \\
\hline Samples & $\mathbf{0}$ & $\mathbf{2 4}$ & $\mathbf{4 8}$ & $\mathbf{7 2}$ & $\mathbf{9 6}$ \\
\hline Gbanja extracts with zobo drink & 1.340 & 1.300 & 1.200 & 1.090 & 0.940 \\
\hline Abata extracts with zobo drink & 1.340 & 1.280 & 1.200 & 1.070 & 0.870 \\
\hline Zobo drink without extracts & 1.340 & 1.540 & 1.610 & 1.840 & 1.985 \\
\hline
\end{tabular}

Table 5: Changes in the Colony Forming Units (CFU) of Escherichia coli in zobo drink. Colony forming unit cfu/time (hours)

\begin{tabular}{|l|c|c|c|c|c|}
\hline \multicolumn{1}{|c|}{ Samples } & $\mathbf{0}$ & $\mathbf{2 4}$ & $\mathbf{4 8}$ & $\mathbf{7 2}$ & $\mathbf{9 6}$ \\
\hline Gbanja extracts with zobo drink & $2.0 \times 10^{4}$ & $1.8 \times 10^{4}$ & $1.5 \times 10^{3}$ & $1.8 \times 10^{2}$ & $1.5 \times 10^{2}$ \\
\hline Abata extracts with zobo drink & $2.0 \times 10^{4}$ & $1.9 \times 10^{4}$ & $1.4 \times 10^{4}$ & $1.2 \times 10^{4}$ & $1.0 \times 10^{3}$ \\
\hline Zobo drink without extracts & $2.0 \times 10^{4}$ & $3.2 \times 10^{4}$ & $2.5 \times 10^{5}$ & $3.2 \times 10^{5}$ & $4.2 \times 10^{5}$ \\
\hline
\end{tabular}

\subsection{Physiochemical Analysis of Kolanut Samples}

The physiochemical analysis of the kolanut samples as earlier calculated revealed that the ash content for Gbanja and Abata were 1.2\% and 1.6\% respectively. The caffeine content from Gbanja and Abata samples were $2.958 \%$ and $3.782 \%$ respectively. The result showed that Gbanja sample was high in both ash and caffeine content when compared to Abata. However, the caffeine content obtained disagreed with the result obtained by (Kordylase, 1990) with caffeine content of $2 \%$. 


\section{4 pH Determination of Samples}

The $\mathrm{pH}$ reading of all the samples investigated was as shown in Table 1 . The result showed that both the Kolanut extracts and the zobo drink samples were within the acidic range for food samples. $\mathrm{pH}$ measurement is important physiochemical parameter that tends to ensure good shelf stability of food samples. High acid range food confers more antimicrobial effects on contaminating organisms.

\subsection{Changes in the pH Reading during Antimicrobial Experiment with Zobo Drink}

Table 2 revealed that there was a gradual reduction in the $\mathrm{pH}$ of the medium to an acidic range. The gradual acidic release might prevent the multiplication of the Escherichia coli which is the indicator organisms. The control samples however, showed an increase in $\mathrm{pH}$ with time.

\subsection{Changes in the Brix Content during Antimicrobial Experiment with Zobo Drink}

Changes in the Brix content revealed that the Kolanut extracts sample were able to maintain the sugar level throughout the period of experiment. The caffeine content from the Kolanut samples might have hindered the fermentation by the indicator organism (Escherichia coli). The control utilization of the sugar in the medium and hence there was a sharp reduction in the sugar content from 15 Brix to 2.0. Brix has shown in Table 3.

\subsection{Changes in the Growth of Escherichia coli in Zobo Drink}

The result revealed that Zobo drink containing the Kolanut extracts showed a downward trend in the growth of the Escherichia coli over time. The control sample however, showed an increased growth of the Escherichia coli over time. The fall in the growth of Escherichia coli in the Zobo drink with Kolanut extracts might have been due to the caffeine; the active ingredients for its antimicrobial effects. The caffeine like other forms of chemical preservatives must have prevented the growth of the indicator organism from growing.

\subsection{Changes in the Colony Forming Unit of Escherichia coli in Zobo Drink}

Table 5 showed that Zobo drink containing the Kolanut extract had a gradual fall in the growth number of inoculated Escherichia coli when compared to the control (without the growth) that had an increased number in the growth of the inoculated Escherichia coli.

\section{Conclusion}

Zobo drink is a product made from the calyces of Hibiscus sabdariffa using hot water extraction. The product was formulated and prevention of the product with kolanuts of Kola acuminata and Kola nitida was very effective using Escherichia coli as the indicator organism. The use of preservatives in the preservation of Zobo drink is highly very necessary since the drink is prone to fermentation during storage. The use of the Kolanut extracts has helped to arrest the growth of the micro-organisms and hence, helped in the maintenance of the product during storage.

\section{Recommendation}

Zobo drink is a highly refreshing drink that is consumed by majority of Nigerians. The use of Kolanut extracts will therefore help to increase the shelve life of the products for its consumption at anytime. The use of Kolanut extracts will also help to retain the quality of the products. It is on the 
basis of this that the use of Kolanut extracts is therefore recommended in the preservation of Zobo drink.

\section{References}

Ameh,A.O., Isa, M.T., Ahmed A.S. and Adamu S.B. (2009). Studies on the use of Troma in improving the taste of the Extract from Hibiscus Sabadariffa Calyx; Nigerian J ournal of Pharmaceutical; Vol 8No1, ISSN:0189-823x

Braide, W, Oranusi,S. and Peter-Ikechukwu, A.I (2012). Perspectives in the hurdle techniques in the preservation of a non alcoholic beverage, zobo; African Journal of Food Science and Technology Vol. 3(2) pp. 46-52. Available online http://www.interesjournals.org/AJ FST Copyright (c 2012 International Research Journals

Nwachukwu, E., Onovo, O.M. and Ezeama, C.F. (2007). Effect of Lime Juice on the Bacterial Quality of Zobo Drinks Locally Produced in Nigeria. Science Alert. An Open Access Publisher

Nwafor, O. E. and Ikenebomeh M. J. (2009). Effect of sodium benzoate on the growth and enzyme activity of Aspergillus niger and Penicillium citrinum in Zobo drink during storage at $30 \pm 2{ }^{\circ} \mathrm{C}$; African Journal of Biotechnology Vol. 8 (12), pp. 2843-2447, 17 June, 2009 Available online at http://www.academicjournals.org/AJ B ISSN 1684-5315 @ 2009 Academic Journals 
